\title{
Analysis of the relationship between company characteristics and key audit matters disclosed*
}

\author{
Catarina Ferreira ${ }^{1}$ \\ (D) https://orcid.org/0000-0002-1533-1895 \\ Email: 144031@aln.iseg.ulisboa.pt
}

\author{
Ana Isabel Morais ${ }^{2}$ \\ (D) https://orcid.org/0000-0001-7251-6418 \\ Email: anamorais@iseg.ulisboa.pt
}

1 Universidade de Lisboa, Instituto Superior de Economia e Gestão, Lisboa, Portugal

2 Universidade de Lisboa, Instituto Superior de Economia e Gestão, Advance/CSG, Lisboa, Portugal

Received on 11.06.2018 - Desk acceptance on 12.05.2018 - $3^{\text {rd }}$ version approved on 06.26.2019 - Ahead of print on 10.14.2019 Associate Editor: Eliseu Martins

\begin{abstract}
The general objective of this study is to analyze whether the particularities of audited companies influence the volume of key audit matters (KAMs). Its specific objectives are to identify the number of KAMs disclosed by Brazilian companies and analyze the main factors associated with their disclosure. The paper aims to contribute to an area of investigation still lacking in studies that analyze the factors affecting KAM disclosure, which makes audit reports more individualized. The study contributes to understanding the main auditing issues in Brazilian companies that auditors consider relevant, by providing evidence on factors associated with their disclosure. This research is relevant for agencies that issue auditing standards and for financial information users. For issuers of auditing standards, the study is relevant because it identifies the factors associated with KAM disclosure, enabling it to be confirmed that the new audit report model has contributed to its destandardization. For financial information users, the study demonstrates that KAM disclosure varies from company to company, thus contributing to greater transparency of the audit report. Data were collected from the Audit Reports and Consolidated Financial Statements of the 447 Brazilian companies listed on the São Paulo Securities, Commodities, and Futures Exchange (BM\&FBovespa), on December $31^{\text {st }}$ of 2016, and an ordinary least squares (OLS) regression was applied to the defined model. The results show a positive relationship between the number of KAMs disclosed and both the auditor being a Big 4 and the complexity of the audited company. The auditor's fees and auditor's opinion being modified show a negative relationship with the number of KAMs. The article is relevant for companies, auditors, and regulatory and supervisory bodies as it identifies company characteristics that influence KAM disclosure and are determinants for the non-standardization of the auditor's report.
\end{abstract}

Keywords: key audit matters, audit opinion determinants, auditor's report.

Correspondence address

Catarina Ferreira

Universidade de Lisboa, Instituto Superior de Economia e Gestão

Rua Miguel Lupi, 1200-781

Lisboa - Portugal

* This study was funded by National Funds through the Foundation for Science and Technology (FCT) within the scope of the funding project under reference n. UID/SOC/04521/2019. 


\section{INTRODUCTION}

The international financial crisis and development of the Brazilian financial market contributed to reinforcing the importance of having independent audits of financial statements that are carried out with quality (Braunbeck, 2010). According to Lin and Hwang (2010), external auditors are responsible for expressing an opinion on financial statements in order to ensure, to a reasonable extent, that they reflect relevant information and reliably represent the financial situation and results presented by a company. From this analysis emerges the audit report. However, its format has been criticized, as it is considered to be quite standardized and not very informative for its users (Bédard, Gonthier-Besacier \& Schatt, 2014).

Thus, the International Auditing and Assurance Standards Board (IAASB) issued International Standard on Auditing (ISA) 701 - Communication of Key Audit Matters (KAMs), in January of 2015 (IAASB, 2015). This new chapter in the audit report consists of disclosing areas that, according to the auditors, have been shown to be critical over the course of their analysis and are relevant for understanding the work carried out by them, as well as the company's financial statements. This standard aims to align audit reports in different countries and also enable a more comprehendible language for financial statement users (Matos, Santos, Rodrigues \& Leite, 2018).

According to Roxo (2016), besides making the final audit report more individualized for the company audited, the entry into force of the standard also provides more information about areas of risk reported through KAMs. The opinion published in the audit report can be influenced by certain characteristics, both of the auditor and of the entity being audited. And it is through an analysis of these characteristics that it becomes possible to verify certain determinants of the quality of audits (Braunbeck, 2010).

Similar to Pinto and Morais (2019), this article uses the theory of Hogarth (1980) regarding the assimilation of information in the judgement and decision-making process to identify the factors that influence the number of KAMs that auditors disclose. As stated by Pinto and Morais (2019), in the KAM disclosure process, auditors can use avoidance or confrontation. The use of avoidance means that the auditor will not disclose a KAM or will delay its disclosure, and avoidance is expected to occur when the auditors consider there to be less responsibility associated with the effects of not disclosing a KAM than disclosing it. The use of confrontation means that the auditor uses compensatory strategies expressed in the expected utility model, in which the auditor is risk averse.
The disclosure of KAMs in the audit report is influenced by the consequences perceived by the auditor in the economic trade-off between the probability of being exposed to litigation and the loss of reputation, on one hand, and the expected cost of losing a client, on the other. Thus, the characteristics of audited companies and the relationship between the auditors and companies audited are expected to be important drivers of the number of KAMs disclosed.

The sample is composed of financial data on 447 Brazilian companies listed on the São Paulo Securities, Commodities, and Futures Exchange (BM\&FBovespa) on December $31^{\text {st }}$ of 2016 . With relation to the methodology, first an analysis was made of the audit report, with the aim of verifying the number of KAMs reported. Then, to analyze the relationship between the main determinants and KAM disclosure, a dependent variable was established corresponding to the number of KAMs. With regards to the independent variables, these were defined based on the previous literature on the determinants of auditors' fees and auditors' opinions. The variables range from auditor characteristics (for example, whether the auditor belongs to the Big 4, the auditor's opinion in the report, and the fees the auditor charges) to characteristics of the company audited. These involve the sector the Brazilian companies are part of, whether they show going concern risk in the year being studied, the number of segments presented, and, finally, the profitability and indebtedness financial indicators. Having defined the variables, the model was tested using the ordinary least squares (OLS) regression.

In the linear regression, the auditor's opinion, the auditor being a Big 4, and the audited company's complexity variables support the hypotheses formulated in the study. Thus, the audit reports of more complex companies, those audited by a Big 4 , and those that present unmodified opinions in these reports include a greater number of KAMs. However, the results also show that, contrary to expectations, the higher the auditor's fees in relation to total assets, the lower the number of KAMs.

This study is relevant as it contributes to identifying and verifying how certain characteristics of the auditor and of the company audited can influence the number of KAMs presented in the audit report. Notably, there is an observed interest in understanding what the determinants are of the disclosure of KAMs to the users of the final audit report. The recent legislative alterations in auditing practices, as well as the development of the market and financial system in Brazil (Niyama, Costa, Dantas \& 
Borges, 2013), reveal the importance of applying this topic to the country. Such interest is also demonstrated by the study from Cruz, Nardi, Figueira, and Menezes da Silva (2018), which identifies the relationship between the content of the new report and the profile of audited and auditing companies. This study differs from that of Cruz et al. (2018) in identifying factors that determine the disclosure of different KAMs.
This paper is divided into five chapters. After the introduction, the framing of this study within the context of the Brazilian market is presented, followed by the literature review, which is subdivided by the variables that give rise to the hypotheses to be studied. The fourth chapter presents the study sample, applied methodology, and a discussion of the results obtained. The paper ends by presenting the conclusions.

\section{FRAMEWORK}

The audit reports issued are based on Brazilian Accounting Standard (NBC TA) n. 700 (Federal Accounting Council [CFC], 2016b), applied to audits in compliance with the international standards issued by the International Federation of Accountants (IFAC, 2017; Roxo, 2016).

According to Castro, Vasconcelos, and Dantas (2017), convergence of the Brazilian standards with the international standards on auditing (ISA) began in 2009. From that date onward, the country has followed the international trend, adhering to the International Financial Reporting Standards (IASB, 2018). Also as of that date, disclosure of the values charged by auditors in fees became mandatory, with Brazilian Securities and Exchange
Commission Instruction n. 480/2009 (CVM, 2009). Both the crisis in the financial market and criticisms of the form of disclosure of the audit report (Braunbeck, 2010) led to the need to reflect on the quality of the work of independent auditors. Thus, in June of 2016, a set of standards came into effect that constitutes the New Independent Auditor's Report (CFC, 2016b). The standards issued include NBC TA 701 - Communication of Key Audit Matters in the Independent Auditor's Report (CFC, 2016a). This standard is a reflection of ISA 701. The New Auditor's Report was introduced due to the need to provide relevant information to financial statement users and has been mandatory for companies listed on the stock exchange from December $31^{\text {st }}$ of 2016 onward (Tavares, 2017).

\section{LITERATURE REVIEW}

The audit report is elaborated according to the opinion formed by the auditor through analysis of a company's financial statements in a particular period. Subsequently, the auditor gives a brief description of the areas audited and issues an opinion regarding the financial statements, that is, a modified or unmodified opinion (Carrington \& Johed, 2014). These authors argue that the audit report is an important document for society, as users base their investment decisions on it.

The financial report is under ever more pressure, not only from regulators, but also from investors and the press. The criticisms relate to the form, content, and value for users (Church, Davis \& McCracken, 2008; Mock et al., 2013; Smieliauskas, Craig \& Amernic, 2008). Users demand a report with more information relating to the company, as well as to the auditing procedure. It is also important to highlight that some authors consider the report to be ineffective in communicating relevant information about the audit to users (Gray, Turner, Coram \& Mock, 2011; Vanstraelen, Schelleman, Meuwissen \&
Hofmann, 2012). The failure in communication relates to the expectation gap between the auditor and the users of the report, defined as the difference between the expectation levels involving the performance predicted by the independent auditor and by the financial statement user. According to Sterzeck (2017), the existence of this difference creates communication inefficiencies, negatively influencing decision making and reducing confidence in the auditing profession.

According to the IAASB (2013), the standardized form of the report was a concern, as it does not respond to users' information needs. Thus, the IAASB (2015) published ISA 701 - Communication of Key Audit Matters (KAMs). This standard introduces a new section in the audit report that consists of matters that the auditors consider to be the most significant in the financial statements and which they have spent the most time on and given the most attention to. The auditors are entirely responsible for deciding which matters were the most relevant in the period analyzed (Dogan \& Arefaine, 2017). The aim of introducing KAMs 
is to provide information on the work carried out by the auditors, that is, to improve the communication of the auditor's report with its users.

Communicating KAMs became effective for audits of financial statements for periods that close on or after December $31^{\text {st }}$ of 2016. In the new section of the audit report, entitled Key Audit Matters, the auditor must describe each KAM as well as including the way it is analyzed in the audit (IAASB, 2015).

According to the IAASB (2015), KAMs will result in a less standardized audit report, conveying specific information about the company and providing transparency. For that reason, the IAASB does not provide examples of what KAMs should be communicated in order to reduce the risk of standardized reports (Dogan \& Arefaine, 2017). These authors also note that the changes in the report enable an increase in transparency, as they disclose not only the areas that need the most attention, but also the risks associated with the company and the way these are managed.

KAMs may thus attract the attention of users, making financial statements more relevant (Orquin \& Loose, 2013) or even acting as substitutes for other disclosures (Christensen, Glover \& Wolfe, 2014).

A more individualized audit report may result in an additional effort on the part of the auditors (Carcello \& Li, 2013; Roxo, 2016). That is, since the auditors are requested to elaborate declarations regarding complex areas (Öhman, 2007), they may expand their procedures and develop quality control processes, resulting in an additional cost due to the increased workload (Bédard et al., 2014). Consequently, this additional effort may result in an increase in auditing fees (Carcello \& Li, 2013), as well as a delay in the report (Bédard et al., 2014). In other words, as a greater total effort is needed in the audit, the introduction of KAMs may lead to an increase in the wait for the report (Knechel, Sharma \& Sharma, 2012). However, Knechel et al. (2012) argue that if the auditors make this effort in advance, there are no reasons for there to be delays in their report.

Certain authors support the argument that the introduction of KAMs will not have the expected consequences, since the information to be provided was already known or expected (Bédard et al., 2014), or when the information is new, it is not conveyed in a way that makes a difference for the users (Ball, 2013). For that reason, previous results demonstrate that the new audit report has symbolic value (Bédard et al., 2014; Church et al., 2008; Mock et al., 2013) and do not report a significant reaction on the part of investors (Minutti-Meza, Gutierrez, Tatum \& Vulcheva, 2015).
When disclosing more information in the report, the auditor should take into account the confidentiality duty, which is defined as "confidentiality of the information acquired in professional and commercial relationships and not disclosing such information to third parties without proper and specific authorization, unless there is a legal or professional right or duty to disclose" (IFAC, 2006). According to Dogan and Arefaine (2017), this contributes to increasing the auditors' risk, since their clients reveal sensitive information and they have to pay attention when disclosing in order not to damage the company audited. Communication by auditors of information understood by clients to go beyond the duty of confidentiality can lead to negative effects, namely loss of the client. Therefore, auditors find that they are impeded from disclosing information that is not known due to the risk of damaging the company. According to Vanstraelen, Schelleman, Imba, and Ra (2011), auditors are willing to disclose the additional information required by a KAM, as long as it does not go beyond the duty of confidentiality. The opinion issued by the auditor can be affected by a series of determinants categorized as factors of a financial and non-financial nature (Caramanis \& Spathis, 2006) and that can be related with characteristics of the audited company, characteristics of the auditor, or of the relationship between the audited company and the auditor. These determinants seek to offer an explanation for the opinion issued by the auditor (Ireland, 2003; Ye, Carson \& Simnett, 2011).

\subsection{Auditor}

One of the variables indicated by the literature as a determinant of the audit opinion is the auditor's size. According to various authors, the Big 4 provide better quality audits (Francis \& Yu, 2009; Krishnan, 2003). This can be explained by their investment in human and financial resources, enabling these auditors to have access to advanced technology and, therefore, they can invest in their auditing processes (Simunic \& Stein 1987). With regards to the auditor's relationship with the client, previous studies have verified that the Big 4 do not compromise their independence (Carcello, Hermanson \& Huss, 2000) and that companies audited by the Big 4 tend to report financial information in a more conservative way (DeAngelo, 1981; Raghunandan \& Rama, 1995). Thus, the existence of a positive relationship is verified between companies audited by the Big 4 and the issuance of an unqualified opinion. This relationship is explained by their capacity to withstand pressure from clients and identify and report non-compliances (Camargo, 2012; 
Lai, 2013). In addition, as revealed in the theory of Dye (1993), auditors that present higher wealth values are more exposed to being at risk, in the case of litigation or regulatory sanctions. Thus, KAM disclosure can be understood as a way for auditors to communicate issues that they consider relevant without, however, subjecting themselves to the consequences that the disclosure of qualifications can have. As a result, the Big 4 are expected to report a greater number of KAMs.

$\mathrm{H}_{1}$ : there is a positive association between a company being audited by a Big 4 and the number of KAMs.

\subsection{Fees}

Previous studies show that audit fees may be positively associated with perceived risk (Lyon, 2005). Yang (2018) concludes that audit fees are positively related with the company's specific financial, strategic, and operational risks. Previous studies also demonstrate that companies in which there are relevant deficiencies in internal controls have significantly higher audit fees (Hogan \& Wilkins, 2008; Munsif, Raghunandan, Rama \& Singhvi, 2011). It is evident that carrying out an internal audit contributes to reducing fees (Felix \& Gramling, 2001). The governance level affects the value of the fees for audit services to be executed, as well as the number of hours estimated for them to be carried out (Castro, Peleias \& Silva, 2015). Thus, auditors charge clients higher fees when greater governance risks are verified (Bortolon, Sarlo \& Santos, 2013). Previous studies argue that greater governance levels lead to more being spent on auditing, as they require more effort on the part of the auditor and greater monitoring of the client (Hallak \& Silva, 2012; Yatim, Kent $\&$ Clarkson, 2006). Various authors distinguish the fees charged by the Big 4 as premium fees in relation to other auditors in the market (Hallak \& Silva, 2012; Palmrose, 1986), revealing the quality of the procedures practiced and also the fact that the market reacts favorably when the client is audited by an auditor from this group (Lennox, 1999). In this context, the association between KAM disclosure and audit fees may be positive.

$\mathrm{H}_{2}$ : there is a positive association between the value of the fees charged by the auditors and the number of KAMs.

\subsection{Auditor's Opinion}

According to the standards from CFC, the auditor must form an opinion regarding whether the financial statements are elaborated, in all relevant aspects, according to the applicable financial report structure. To form this opinion, the auditor must conclude whether reasonable certainty has been obtained regarding whether the full set of financial statements do not present relevant misstatements, independently of whether they are caused by fraud or error. If the auditors conclude, based on the audit evidence obtained, that the financial statements present relevant misstatements, or if they are not able to obtain sufficient and appropriate audit evidence, they should issue a modified opinion. Previous studies demonstrate that given the consequences that issuing a qualified opinion can have for the clients, auditors have little margin for negotiating with them regarding the compliance of the financial statements with the accounting standards (Cipriano, Hamilton \& Vandervelde, 2017). Despite not being able to substitute qualifications for KAMs (and vice-versa), the consequences of a qualified opinion can lead to auditors taking advantage of relevant auditing issues to describe situations of greater risk for companies. Thus, when issuing an unqualified opinion of the financial statements, the auditor may be likely to present a greater number of reported KAMs.

$\mathrm{H}_{3}$ : there is a negative association between the auditor's opinion and the number of KAMs.

\subsection{Complexity}

A variable is needed that incorporates the company's complexity in order to understand how this behaves with the introduction of the standard being studied. This explanatory variable is the number of segments reported by the company in its financial report, since previous studies address the advantages of this form of reporting. Namely, the possibility of a better perception regarding the risks and opportunities results in the ability to influence investors in their decision making (Berger \& Hann, 2003). Consequently, an increase in the client's complexity leads to greater attention from the auditor, and the more segments the company is in, the greater the number of KAMs expected.

$\mathrm{H}_{4}$ : there is a positive association between the complexity of the company audited and the number of KAMs.

\subsection{Going concern Risk}

The uncertainty relating to the company's capacity for going concern is considered to be a determinant of the opinion formed by the auditor. The evaluation of the capacity is made through judgement about the 
uncertainty of the company's future earnings (Marques \& Souza, 2017). When issuing an opinion involving operational going concern risk, auditors must assess the consequences for their clients. That is, the auditor must weigh issuing an opinion with going concern risk that is not subsequently verified (type I error) against not issuing such an opinion and the client failing (type II error) (Matsumura, Subramanyam \& Tucker, 1997; Tucker, Matsumura \& Subramanyam, 2003). Previous studies reveal that auditors are more willing to disclose an opinion with going concern risk when the company in question is less profitable (Lee, Jiang \& Anandarajan, 2005; Menon \& Schwartz, 1987), reveals high levels of leverage (Raghunandan \& Rama, 1995), presents reduced liquidity (Menon \& Schwartz, 1987; Raghunandan \& Rama, 1995), and is small in size (Mutchler, Hopwood \& McKeown, 1997). Recording losses in consecutive years is also an indicator for the auditor to assess the capacity for going concern (Gallizo \& Saladrigues, 2016), and uncertainty in relation to the estimates of the company's bankruptcy risk increases the possibility of obtaining an opinion with operational going concern risk (Lennox \& Kausar, 2017). To protect their reputation and reduce the risk of litigation, auditors are likely to disclose more KAMs in companies with greater going concern risk. These companies will tend to see their financial information being analyzed in more detail by the auditors. The increase in the auditors' efforts to reduce their responsibility tends to improve the auditing procedures and, therefore, the identification of KAMs. Previous studies also demonstrate that clients of the Big 4 have a lesser tendency to receive an opinion with going concern risk (Reichelt \& Wang, 2010) due to these clients being in a better financial position and their presenting a lower level of manipulation (Becker, DeFond, Jiambalvo \& Subramanyam, 1998; Francis, Michas \& Yu, 2013).

Therefore, the disclosure of an opinion with going concern risk is expected to be associated with a greater number of KAMs in the company's audit report.

$\mathrm{H}_{5}$ : there is a positive association between the existence of an opinion of or emphasis on going concern and the number of KAMs.

\subsection{Financial Performance}

Zanchun, Chun, and Jianming (2010) and Habib (2013) reveal that companies with a higher level of return are associated with a better audit opinion, since they do not need to manipulate their information in order to please the market. In addition, profitability is generally associated with future viability. Therefore, the most profitable companies tend to have a lower probability of non-compliance and receive an unmodified auditor's opinion (Beasley, Carcello \& Hermanson, 1999; Laitenen \& Laitenen, 1998; Loebbecke, Eining, M. \& Willingham, 1989), which reduces the conflict between the auditor and the company. Bellovary, Giacomino, and Akers (2007) also reveal that profitability is a factor that explains the inclusion of an opinion with going concern risk, that is, the higher the level of return, the greater the probability of the company receiving an opinion with this risk. Thus, it is probable that auditors of less profitable companies, with a greater operational risk, feel more pressured to disclosed KAMs in order to ensure their independence. We predict a negative association between the profitability of companies and the number of KAMs disclosed.

$\mathrm{H}_{6}$ : there is a negative association between the audited company's profitability and the number of KAMs.

\subsection{Financial Indebtedness}

Dopuch, Holthausen, and Leftwich (1987) verified that characteristics of audited companies were fundamental for predicting the auditor's opinion, and the disclosure of losses was significant in determining this opinion. Previous studies demonstrate that companies with losses present indications of greater risk (Ireland, 2003; Ye et al., 2011) and, therefore, auditors tend to review those companies in more detail, which results in an increase in effort on the part of the auditors. This increase in effort from the auditors to reduce their responsibility tends to improve the auditing procedures and, therefore, the identification of KAMs.

In addition, Chan and Walter (1996) reveal that companies with a high debt value present greater financial risk. Auditors should thus pay extra attention. Hence, more indebted companies are expected to reveal a greater number of KAMs.

$\mathrm{H}_{7}$ : there is a positive association between the company's level of indebtedness and the number of KAMs. 


\section{EMPIRICAL STUDY}

This paper aims to identify the number of KAMs disclosed by Brazilian companies and the main factors associated with that disclosure.

\subsection{Sample}

The sample in this study is composed of the Brazilian companies listed on the BM\&FBovespa. Financial data on 448 companies were collected, and those that did not present the data needed to verify the previously formulated hypotheses were excluded, resulting in a final sample composed of 447 companies. Table 1 presents the classification of the companies by sector, following the division currently used by the BM\&FBovespa. With relation to the data, these were collected through an analysis of the information in the Audit Reports released by the companies, as well as the Consolidated Financial Statements and respective Notes. The study sample corresponds to 2016, the year in which communication of KAMs was introduced in the audit reports.

Table 1

Description of the final sample

\begin{tabular}{|c|c|c|}
\hline \multirow{2}{*}{ Segment/sector } & \multicolumn{2}{|c|}{ Companies } \\
\hline & (n) & $(\%)$ \\
\hline Financial & 119 & 27 \\
\hline Cyclical consumer & 79 & 18 \\
\hline Non-cyclical consumer & 24 & 5 \\
\hline Public utility & 66 & 15 \\
\hline Health & 18 & 4 \\
\hline Telecommunciations & 6 & 1 \\
\hline Industrial goods & 73 & 16 \\
\hline Basic materials & 32 & 7 \\
\hline Oil, gas, and biofuels & 11 & 2 \\
\hline Information technology & 7 & 2 \\
\hline Not classified & 12 & 3 \\
\hline Total & 447 & 100 \\
\hline
\end{tabular}

Source: Elaborated by the authors.

The most represented activity sectors in the final sample are financial, with $27 \%$ of the entities, consumer, with $23 \%$, industrial goods, with $16 \%$, and public utility, with $15 \%$.

\subsection{Methodology}

To achieve the paper's first objective, the audit reports were analyzed, in order to identify the number of KAMs disclosed. To accomplish the second objective (verifying the main determinants of KAM disclosure), the number of KAMs was defined as the dependent variable. With relation to the independent variables that explain the model, eight variables were defined based on the literature review, which take into account not only the characteristics of the auditor, but also those of the company audited. A multiple regression model was used with the aim of responding to the investigation hypotheses. The OLS method is employed, defined as follows:

$$
\begin{gathered}
\text { KAM }=\beta 0+\beta 1 \text { Audit }+\beta 2 \text { Fees }+\beta 3 \text { Modif }+\beta 4 \text { Segm }+\beta 5 C R+\beta 6 R O A+ \\
\beta 7 \text { Indeb }+\beta 8 \text { Sect_Finan }+\beta 9 S e c t+C C+\beta 10 S e c t+C n c+\beta 11 \text { Sect_PU }+ \\
\beta 12 \text { Sect_Health }+\beta 13 \text { Sect_Tele }+\beta 14 \text { Sect_IG }+\beta 15 \text { Sect_BM }+\beta 16 \text { Sect_Oil }+ \\
\beta 17 \text { Sect_IT }+\varepsilon
\end{gathered}
$$

in which KAM is the number of KAMs present in the final audit report, Audit is the type of auditor that made that report (it takes the value of 1 when the auditor is a
Big 4 and 0 otherwise), Fees are the fees charged by the auditors divided by total assets (in reais), Modif is an opinion of the report to be modified (it takes the value of 
1 when the report is modified and 0 otherwise), Segm is the number of segments the audited company's business line is divided into, CR is the audited company's going concern risk (it takes the value of 1 when there is going concern risk in the audit report and 0 otherwise), ROA is the audited company's financial return, calculated as net earnings divided by total assets (in reais), Indeb is the audited company's level of indebtedness, calculated as the ratio between total liabilities and total assets (in reais), Sect-Finan is the financial sector, Sect_CC is the cyclical consumer sector, Sect_NCC is the non-cyclical consumer sector, Sect_PU is the public utility sector, Sect_Health is the health sector, Sect_Tele is the telecommunications sector, Sect_IG is the industrial goods sector, Sect_BM is the basic materials sector, Sect_Oil is the oil, gas, and biofuels sector, and Sect_IT is the information technology sector.

\subsection{Results Analysis}

Table 2 presents the descriptive statistics for the dependent variable and the independent variables.

Table 2

Descriptive statistics of the dependent and independent variables

\begin{tabular}{|c|c|c|c|c|c|}
\hline Variable & Mean & Median & Standard deviation & Minimum & Maximum \\
\hline Key audit matters (KAMs) & 2.4359 & 1 & 1.5078 & 0 & 8 \\
\hline Auditor & 0.7136 & 1 & 0.4526 & 0 & 1 \\
\hline Fees & 0.096 & 0.0002 & 0.0526 & 0.000 & 0.46 \\
\hline Modified auditor's opinion & 0.0538 & 0 & 0.2259 & 0 & 1 \\
\hline Financial sector & 0.2662 & 0 & 0.4425 & 0 & 1 \\
\hline Cyclical consumer sector & 0.1767 & 0 & 0.3819 & 0 & 1 \\
\hline Non-cyclical consumer sector & 0.0537 & 0 & 0.2257 & 0 & 1 \\
\hline Public utility sector & 0.1477 & 0 & 0.3552 & 0 & 1 \\
\hline Health sector & 0.0403 & 0 & 0.1968 & 0 & 1 \\
\hline Telecommunications sector & 0.0134 & 0 & 0.1152 & 0 & 1 \\
\hline Industrial goods sector & 0.1633 & 0 & 0.3701 & 0 & 1 \\
\hline Basic materials sector & 0.0716 & 0 & 0.2581 & 0 & 1 \\
\hline Oil, gas, and biofuels sector & 0.0246 & 0 & 0.1551 & 0 & 1 \\
\hline Information technology sector & 0.0157 & 0 & 0.1243 & 0 & 1 \\
\hline Complexity & 1.639 & 1 & 1.7032 & 0 & 8 \\
\hline Going concern risk & 0.1816 & 0 & 0.3859 & 0 & 1 \\
\hline Profitability & -0.4817 & 0.0126 & 4.0639 & -70.2482 & 4.5279 \\
\hline Indebtedness & 7.7385 & 0.6414 & 133.1524 & 0 & $2,802.4061$ \\
\hline
\end{tabular}

Source: Elaborated by the authors.

The dependent variable reveals a total of 1,084 reported KAMs relating to the companies in the sample. The mean value in the audit reports relating to the 2016 period is 2.436 KAMs per company, with a standard deviation of 1.508 . With relation to the mean KAM value per company in other countries, the United Kingdom shows a mean of 4.1 KAMs and France and Cyprus have an average of two KAMs in their audit reports [Association of Chartered Certified Accountants (ACCA), 2018; Bédard et al., 2014]. The median indicates one KAM in the final report and the maximum number of KAMs present in the reports is eight. In comparison with previous studies (Vik \& Walter, 2017), Norway presents a maximum value of five KAMs and the Netherlands has a maximum of six KAMs in its reports.
With relation to the independent variables, the mean of the auditor type shows that $71.36 \%$ of the companies listed on the stock exchange in Brazil are audited by a Big 4. It is also possible to ascertain that, on average, the Big 4 report 2.61 KAMs in their reports, while the nonBig 4 auditors present 1.95 KAMs. As for the modified opinion variable, this shows that, on average, $5.38 \%$ of the companies listed on the stock exchange have a modified opinion. The percentage of KAMs reported for companies issuing an unmodified opinion is $2.95 \%$. With regards to going concern risk, the mean value of companies that present this risk is $18.16 \%$.

The most representative sector type in the sample in this study is financial, indicating a mean of $26.62 \%$. This means that approximately one fourth of the listed 
companies in Brazil form part of the financial sector. The telecommunications and information technology sectors are the ones with the least presence, with means of $1.34 \%$ and $1.56 \%$, respectively.

The mean value of the fees charged by the auditors in relation to total assets is 0.096 , with a standard deviation of 0.0526 .

Regarding the complexity of the companies in the sample, the mean number of segments is 1.639 , with a standard deviation of 1.703 . The median shows one business segment in the audited companies. The minimum amount of segments is zero and the maximum amount is eight segments.

With relation to the financial performance indicators, financial return presents a mean value of -0.482 , with a standard deviation of 4.064 . The minimum profitability value is -70.248 , the maximum is 4.528 , and the median profitability value of the listed companies is 0.013 . The mean value of this variable indicates that the return on assets is not positive; that is, the companies studied do not have the capacity to generate earnings based on their assets. With relation to the indebtedness indicator, the mean value of the sample is 7.739 , with a standard deviation of 133.152. That is, the audited companies reveal an inability to fund their assets by resorting to liabilities. The median of this variable is 0.641 , taking 0 as the minimum value and $2,802.406$ as the maximum. In this case, the maximum value appears to be an outlier of the study.

Through the multiple linear regression, it is possible to verify the relationship between the dependent variable of the study and the other independent variables, represented in Table 3. The model has the ability to explain the relationship between the variables and has a coefficient of determination that indicates that the independent variables of the model explain $18.3 \%$ of the variance of the KAM variable.

In addition, the VIF (variance inflation factors) test was carried out in order to dismiss the possibility of the existence of multicollinearity between the independent variables. It was verified that this existence is unlikely, since all the values are lower than 10 (results not tabulated), as well as all the variables being included in the regression. Heteroscedasticity was also analyzed, using the BreuschPagan-Gofrey test, and it was concluded that there is no heteroscedasticity.

Table 3

Results obtained using the linear regression

\begin{tabular}{|c|c|c|c|}
\hline Variables & Expected sign & Coefficient & p-value \\
\hline Auditor & + & 0.131 & $2.663^{* * *}$ \\
\hline Fees & + & -0.176 & $-3.086^{* * *}$ \\
\hline Auditor's opinion & - & -0.164 & $-3.357^{* * *}$ \\
\hline Financial sector & & 0.157 & 1.231 \\
\hline Cyclical consumer sector & & 0.190 & $1.678^{*}$ \\
\hline Non-cyclical consumer sector & & 0.076 & 0.973 \\
\hline Public utility sector & & 0.238 & $2.221^{* *}$ \\
\hline Health sector & & 0.051 & 0.727 \\
\hline Telecommunications sector & & 0.006 & 0.104 \\
\hline Industrial goods sector & & 0.217 & $1.945^{*}$ \\
\hline Basic materials sector & & 0.168 & $1.966^{* *}$ \\
\hline Oil, gas, and biofuels sector & & 0.160 & $2.584^{* * *}$ \\
\hline Information technology sector & & 0.099 & $1.755^{*}$ \\
\hline Complexity & + & 0.197 & $4.129 * * *$ \\
\hline Going concern risk & + & -0.018 & -0.341 \\
\hline Profitability & + & 0.014 & 0.246 \\
\hline Indebtedness & + & 0.038 & 0.758 \\
\hline $\mathrm{N}$ & & 419 & \\
\hline $\mathrm{R}^{2}$ & & 0.162 & \\
\hline $\mathrm{F}$ test & & 5.844 & $<0.0001$ \\
\hline Multicollinearity (variance inflation factor - VIF) & & 3.00 & \\
\hline Heteroscedasticity (Breusch-Pagan-Gofrey) & & 0.92 & \\
\hline
\end{tabular}

$*, * *, * * *=10,5$, and $1 \%$ significance level, respectively.

Source: Elaborated by the authors. 
To analyze the individual statistical significance of the independent variables of the model, the $t$ test was carried out. It was verified that the auditor type, auditor's opinion, fees, and company complexity variables have a lower $\mathrm{p}$-value than the significance level. Hence, it is possible to reject the null hypothesis and demonstrate that the coefficient of these variables is significant for that level of significance. The going concern risk, indebtedness, and profitability variables present a higher $\mathrm{p}$-value, and thus they will not reject the null hypothesis. This also means that there is statistical evidence that their coefficients are not significant for a $10 \%$ significance level and, consequently, at the other levels.

The most complex companies tend to have more KAMs in their audit reports. There is thus a positive association between the company's complexity and the number of KAMs, and hence $\mathrm{H}_{4}$ is verified. It is therefore proven that the disclosure of KAMs depends on the complexity of the company audited (Cordos \& Fülop, 2015; Cruz et al., 2018). The results reveal that companies audited by the Big 4 tend to present more KAMs in their audit reports. The coefficient of the auditor variable is positive and statistically significant, thus supporting $\mathrm{H}_{1}$, similarly to the result found in the study by Cruz et al. (2018). From the coefficient of the auditor's opinion, which is negative and statistically significant, it is possible to determine that companies with audit reports in which the auditor's opinion is modified present fewer KAMs, thus verifying $\mathrm{H}_{3}$. In the study by Cruz et al. (2018), the auditor's opinion variable is not statistically significant.

Contrary to expectations, it is verified that companies whose weight of fees over total assets is greater present fewer KAMs. Thus, $\mathrm{H}_{2}$ is rejected. As explained by Pinto and Morais (2019), this result can be explained by the fact that the auditor's decision to disclose a KAM may be a choice between maintaining its reputation and maintaining a certain level of return. DeAngelo (1981) indicates that auditors are more likely to question their independence in relation to more important clients. McKeown, Mutchler, and Hopwood (1991) conclude that the biggest clients take advantage of their argumentation power and, consequently, are more likely to receive a qualified opinion. Reynolds and Francis (2000) investigate the influence of larger-sized clients on the decisions in auditors' reports and conclude that economic factors can incentivize auditors to agree with the clients' decisions in terms of financial reports solely to keep them as clients.

Finally, and since the entities in the financial sector present different specificities, regulations, and supervision from other sectors, the regression model was verified again, excluding the financial sector entities. The results (not tabulated) reveal that the coefficient of the complexity variable continues to be positive and statistically significant, indicating that the most complex companies tend to have more KAMs disclosed in their audit reports. The auditor's opinion variable continues to present a negative and statistically significant coefficient, indicating that companies with modified opinions in the audit report tend to have fewer KAMs in that report. The results are, however, different compared to those presented in Table 3 in two aspects: first, the auditor variable ceases to be statistically significant; and the fees over total assets variable presents a negative, but not statistically significant coefficient.

\section{CONCLUSIONS}

This study aims to identify the number of KAMs reported for Brazilian listed companies and verify what the determinants of that disclosure are. Thus, the audit reports and financial statements presented by the Brazilian companies listed on the stock exchange were examined, in order to collect the data needed to then build the descriptive statistics and apply regression methods. The results obtained reveal that when a Big 4 auditor draws up the final audit report, a greater number of reported KAMs are expected. Also, higher fees charged by the auditor will result in a lower number of KAMs. However, when the auditor's opinion is modified, fewer KAMs are disclosed in the audit report. With relation to the determinants of the characteristics of the audited company, a higher number of KAMs is expected when the company is more complex.
This study contributes to expanding the literature on the entry into force of ISA 701 in the current audit report, investigating the relationship with determinant characteristics for the disclosure of the auditor's opinion. It is important to highlight that the sample focuses on a recent period, it is more comprehensive than in previous studies (Tavares, 2017), and it contemplates different determinants of KAM disclosure from previous studies (Cruz et al., 2018).

This study's main limitation relates to the defined sample, since it only takes Brazilian listed companies into account and thus creates the impossibility of comparing the communication of KAMs with the determinants of the opinion in different financial and economic situations. Moreover, this study only covers 2016. 


\section{REFERENCES}

Association of Chartered Certified Accountants. (2018). Key audit matters: Unlocking the secrets of the audit. ACCA. Retrieved from https://www.accaglobal.com/vn/en/professionalinsights/global-profession/key-audit-matters.html

Ball, R. (2013). Accounting informs investors and earnings management is rife: Two questionable beliefs. Accounting Horizons, 27(4), 847-853.

Beasley, M., Carcello, J., \& Hermanson, D. (1999). Fraudulent financial reporting: 1987-1997. An analysis of U.S. public companies. New York, NY: COSO.

Becker, C., DeFond, M., Jiambalvo, J., \& Subramanyam, K. (1998). The effect of audit quality on earnings management. Contemporary Accounting Research, 15(1), 1-24.

Bédard, J., Gonthier-Besacier, N., \& Schatt, A. (2014). Costs and benefits of reporting key audit matters in the audit report: The French experience. International Symposium on Audit Research. Retrieved from http://www.isarhq.org/2014 downloads/papers/ISAR2014_Bedard_Besacier_Schatt.pdf

Bellovary, J., Giacomino, D., \& Akers, M. (2007). A review of bankruptcy prediction studies: 1930 to present. Journal of Financial Education, 33, 1-42.

Berger, P., \& Hann, R. (2003). The impact of SFAS No. 131 on information and monitoring. Journal of Accounting Research, 41(2), 163-223.

Bortolon, P., Sarlo, A., \& Santos, T. (2013). Custos de auditoria e governança corporativa. Revista Contabilidade \& Finanças, 24(61), 27-36.

Braunbeck, G. (2010). Determinantes da qualidade das auditorias independentes no Brasil (Doctoral Thesis). Universidade de São Paulo, São Paulo.

Camargo, R. (2012). Determinantes dos pareceres dos auditores independentes emitidos às companhias negociadas na $B M \& F B O V E S P A$ (Master's Dissertation). Universidade Federal de Santa Catarina, Florianópolis.

Caramanis, C., \& Spathis, C. (2006). Auditee and audit firm characteristics as determinants of audit qualifications: Evidence from the Athens stock exchange. Managerial Auditing Journal, 21(9), 905-920.

Carcello, J., \& Li, C. (2013). Costs and benefits of requiring an engagement partner signature: Recent experience in the United Kingdom. The Accounting Review, 88(5), 1511-1546.

Carcello, J., Hermanson, D., \& Huss, H. (2000). Going-concern opinions: The effects of partner compensation plans and client size. Auditing: A Journal of Practice \& Theory, 19(1), 67-77.

Carrington, T., \& Johed, G. (2014). How the business press stabilizes and destabilizes notions of audit failure. The case of Intrum Justitia. In Pallas, J., Strannegård, L., \& Jonsson, L. (Ed.), Organizations and the media organizing in a mediatized world (pp. 116-131). New York, NY: Routledge.

Castro, R., Vasconcelos, J., \& Dantas, J. (2017). Impactos das normas internacionais de auditoria nos relatórios dos auditores sobre as demonstrações financeiras dos bancos brasileiros. Revista Ambiente Contábil, 9(1), 1-20.
Castro, W. Peleias, I., \& Silva, G. (2015). Determinantes dos honorários de auditoria: um estudo nas empresas listadas na BM\&FBovespa. Revista Contabilidade \& Finanças, 26(69), 261-273.

Chan, Y., \& Walter, T. (1996). Qualified audit reports and costly contracting. Asia Pacific Journal of Management, 13(1), 37-63.

Christensen, B. , Glover S., \& Wolfe C. (2014). Do critical audit matter paragraphs in the audit report change nonprofessional investors' decision to invest? Auditing: A Journal of Practice \& Theory, 33(4), 71-93.

Church, B., Davis, S., \& McCracken, S. (2008). The auditor's reporting model: A literature overview and research synthesis. Accounting Horizons, 22(1), 69-90.

Cipriano, M., Hamilton, E., \& Vandervelde, S. (2017). Has the lack of use of the qualified audit opinion turned it into the "Rotten Kid" threat? Critical Perspectives on Accounting, 47(1), 26-38.

Comissão de Valores Mobiliários (Brazilian Securities and Exchange Commission). (2009). CVM Instruction n. 480, of December $7^{\text {th }}$ of 2009. Discusses registering issuers of securities accepted for trading in regulated securities markets. Retrieved from file:///C:/Users/User/Downloads/inst480.pdf.

Conselho Federal de Contabilidade (Federal Accounting Council). (2016a). Brazilian Accounting Standard n. 701, of June $17^{\text {th }}$ of 2016. Communication of Key Audit Matters in the Independent Auditor's Report. Retrieved from https://www. legisweb.com.br/legislacao/?id=325606

Conselho Federal de Contabilidade (Federal Accounting Council). (2016b). Brazilian Accounting Standard n. 700, of June $17^{\text {th }}$ of 2016. Gives new wording to NBC TA 700, which discusses the formation of the opinion and publication of the independent auditor's report on the financial statements. Retrieved from https://www.legisweb.com.br/legislacao/?id=325605

Cordos, G., \& Fülöp, M. (2015). Understanding audit reporting changes: introduction of Key Audit Matters. Accounting \& Management Information Systems, 14(1), 128-152.

Cruz, A., Nardi, P., Figueira, L., \& Menezes da Silva, R. (2018). A relação entre o novo relatório do auditor independente e o perfil das empresas. XV Congresso USP de Iniciação Científica em Contabilidade. Retrieved from https://congressousp.fipecafi. org/anais/Anais2018/ArtigosDownload/781.pdf

DeAngelo, L. (1981). Auditor size and audit quality. Journal of Accounting and Economics, 3(3), 183-199.

Dogan, B., \& Arefaine, B. (2017). The implementation of ISA 701 Key audit matters: Empirical evidence on auditors adjustments in the new audit report (Master's Dissertation). Uppsala University, Uppsala.

Dopuch, N., Holthausen, R., \& Leftwich, R. (1987). Predicting audit qualifications with financial and market variables. Accounting Review, LXII(3),431-454.

Dye, R. (1993). Auditing standards, legal liabilities, and auditor wealth. Journal of Political Economy, 101(5), 887-914.

Felix, W., Jr., \& Gramling, A. (2001). The contribution of internal audit as a determinant of external audit fees and factors 
influencing this contribution. Journal of Accounting Research, 39(3), 513-534.

Francis, J., \& Yu, M. (2009). Big 4 office size and audit quality. The Accounting Review, 84(5), 1521-1552.

Francis, J., Michas, P., \& Yu, M. (2013). Office size of Big 4 auditors and client restatements. Contemporary Accounting Research, 30(4), 1626-1661.

Gallizo, J., \& Saladrigues, R. (2016). An analysis of determinants of going concern audit opinion: Evidence from Spain stock exchange. Intangible Capital, 12(1), 1-16.

Gray, G., Turner, J., Coram, P., \& Mock, T. (2011). Perceptions and misperceptions regarding the unqualified auditor's report by financial statement preparers, users, and auditors. Accounting Horizons, 25(4), 659-684.

Habib, A. (2013). A meta-analysis of the determinants of modified audit opinion decisions. Managerial Auditing Journal, 28(3), 184-216.

Hallak, R., \& Silva, A. (2012). Determinantes das despesas com serviços de auditoria e consultoria prestados pelo auditor independente no Brasil. Revista Contabilidade \& Finanças, 23(60), 223-231.

Hogan, C., \& Wilkins, M. (2008). Evidence on the audit risk model: Do auditors increase audit fees in the presence of internal control deficiencies? Contemporary Accounting Research, 25(1), 219-242.

Hogarth, R. (1980). Judgement and choice: The psychology of decision. New York, NY: John Wiley \& Sons.

International Accounting Standards Board. (2018). International Financial Reporting Standards. Retrieved from https://www. ifrs.org/issued-standards/list-of-standards/

International Auditing and Assurance Standard Board. (2013). Exposure draft: Reporting on audited financial statements: proposed new and revised International Standards on Auditing (ISAs). New York, NY: International Federation of Accountants.

International Auditing and Assurance Standards Board. (2015). International Standard on Auditing (ISA) 701 (NEW), Communicating Key Audit Matters in the Independent Auditor's Report. IAASB. Retrieved from https://www.ifac.org/ publications-resources/international-standard-auditing-isa701-new-communicating-key-audit-matters-i

International Federation of Accountants. (2006). Code of ethics for professional accountants.

International Federation of Accountants. (2017), International Auditing and Assurance Standards Board, International Standards on Auditing. Retrieved from https://www.ifac.org/ publications-resources

Ireland, J. (2003). An empirical investigation of determinants of audit reports in the UK. Journal of Business Finance \& Accounting, 30(7-8), 975-1016.

Knechel, W., Sharma, D., \& Sharma, V. (2012). Non-audit services and knowledge spillovers: Evidence from New Zealand. Journal of Business Finance \& Accounting, 39(1), 60-81.
Krishnan, G. (2003). Does Big 6 auditor industry expertise constrain earnings management? Accounting Horizons, 17(1), $1-16$.

Lai, K. (2013). Audit reporting of Big 4 versus non-Big 4 auditors: The case of ex-Andersen clients. The International Journal of Accounting, 48(4), 495-524.

Laitinen, E. \& Laitinen, T. (1998). Qualified audit reports in Finland: Evidence from large companies. European Accounting Review, 7(4), 639-653.

Lee, P., Jiang, W., \& Anandarajan, A. (2005). Going concern report modeling: A study of factors influencing the auditor's decision. Journal of Forensic Accounting, 6(1), 55-76.

Lennox, C. S. (1999). Audit quality and auditor size: An evaluation of reputation and deep pockets hypotheses. Journal of Business Finance \& Accounting, 26(7-8), 779-805.

Lennox, C. S., \& Kausar, A. (2017). Estimation risk and auditor conservatism. Review of Accounting Studies, 22(1), 185-216.

Lin, J., \& Hwang, M. (2010). Audit quality, corporate governance, and earnings management: A meta-analysis. International Journal of Auditing, 14(1), 57-77.

Loebbecke, J., Eining, M., \& Willingham, J. (1989). Auditor's experience with material irregularities: Frequency, nature, and detectability. Auditing: A Journal of Practice \& Theory, 9(1), 1-28.

Lyon, J., \& Maher, M. (2005). The importance of business risk in setting audit fees: Evidence from cases of client misconduct. Journal of Accounting Research, 43(1), 133-151.

Marques, V., \& Souza, M. (2017). Principais assuntos de auditoria e opinião sobre o risco de descontinuidade: uma análise das empresas do IBOVESPA. Revista de Informação Contábil, 11(4), 1-22.

Matos, T., Santos, O., Rodrigues, A., \& Leite, R. (2018). Lobbying na regulação de auditoria no âmbito do IAASB. Revista Contabilidade \& Finanças, 29(77), 246-265.

Matsumura, E., Subramanyam, K., \& Tucker, R. (1997). Strategic auditor behavior and going-concern decisions. Journal of Business Finance \& Accounting, 24(6), 727-758.

McKeown, J., Mutchler, J., \& Hopwood, W. (1991). Towards an explanation of auditor failure to modify the audit opinion of bankrupt companies [Supplement]. Auditing: A Journal of Practice and Theory, 1-13.

Menon, K., \& Schwartz, K. (1987). An empirical investigation of audit qualification decisions in the presence of going concern uncertainties. Contemporary Accounting Research, 3(2), 302-315.

Minutti-Meza, M., Gutierrez, E., Tatum, K., \& Vulcheva, M. (2015). Consequences of changing the auditor's report: Early evidence from the UK. Singapore Management University. Retrieved from https://accountancy.smu.edu.sg/sites/ accountancy.smu.edu.sg/files/MiguelMinuttiMeza_paper_1.pdf

Mock, T., Bédard, J., Coram, P., Davis, S., Espahbodi, R., \& Warne, R. (2013). The audit reporting model: Current research synthesis and implications. Auditing: A Journal of Practice \& Theory, 32(1), 323-351. 
Munsif, V., Raghunandan, K., Rama, D., \& Singhvi, M. (2011). Audit fees after remediation of internal control weaknesses. Accounting Horizons, 25(1), 87-105.

Mutchler, J., Hopwood, W., \& McKeown, J. (1997). The influence of contrary information and mitigating factors on audit opinion decisions on bankrupt companies. Journal of Accounting Research, 35(2), 295-310.

Niyama, J., Costa, F., Dantas, J., \& Borges, E. (2013). Evolução da regulação da auditoria independente no Brasil: análise crítica, a partir da teoria da regulação. Advances in Scientific and Applied Accounting, 4(2), 127-161.

Öhman, P. (2007). Perspective on audit: Thoughts, expectations and dilemma (Doctoral Thesis). University Mid Sweden, Sundsvall.

Orquin, J., \& Loose, S. (2013). A review on eye movements in decision making. Acta Psychologica, 144(1), 190-206.

Palmrose, Z. (1986). The effect of non-audit services on the pricing of audit services: Further evidence. Journal of Accounting Research, 24(2), 405-411.

Pinto, I., \& Morais, A. (2019). What matters in disclosures of key audit matters: Evidence from Europe. Journal of International Financial Management and Accounting, 30(2), 145-162.

Raghunandan, K., \& Rama, D. (1995). Audit reports for companies in financial distress: Before and after SAS No. 59. Auditing: A Journal of Practice \& Theory, 14(1), 50-63.

Reichelt, K., \& Wang, D. (2010). National and office-specific measures of auditor industry expertise and effects on audit quality. Journal of Accounting Research, 48(3), 647-686.

Reynolds, J., \& Francis, J. (2000). Does size matter? The influence of large clients on office-level auditor reporting decisions. Journal of Accounting and Economics, 30(3), 375400.

Roxo, G. (2016). Análise das alterações nas normas de auditoria à luz do novo relatório de auditoria independente (Master's Dissertation). Universidade Federal Rio Grande do Sul, Porto Alegre.

Simunic, D., \& Stein, M. (1987). Product differentiation in auditing: Auditor choice in the market for unseasoned new issues. Vancouver: Canadian Certified General Accountants Research Foundation.
Smieliauskas, W., Craig, R., \& Amernic, J. (2008). A proposal to replace 'true and fair view' with 'acceptable risk of material misstatement'. A Journal of Accounting, Finance and Business Studies, 44(3), 225-250.

Sterzeck, G. (2017). Audit expectation gap nos litígios das firmas de auditoria (Master's Dissertation). Universidade de São Paulo, São Paulo.

Tavares, L. C. (2017). Novo relatório dos auditores independentes: um estudo sobre os principais assuntos de auditoria nas companhias listadas na BMF\&FBOVESPA (Master's Dissertation). Universidade Federal do Rio Grande do Norte, Natal.

Tucker, R., Matsumura, E., \& Subramanyam, K.R. (2003). Going-concern judgments: An experimental test of the self-fulfilling prophecy and forecast accuracy. Journal of Accounting and Public Policy, 22(5), 401-432.

Vanstraelen, A., Schelleman, C., Imba, I., \& Ra, R. (2011). A framework for extended audit reporting. Maastricht Accounting, Auditing and Information Management Research Center. Retrieved from https://www.accaglobal.com/content/ dam/acca/global/PDF-technical/audit-publications/extended audit_reporting.pdf

Vanstraelen, A., Schelleman, C., Meuwissen, R., \& Hofmann, I. (2012). The audit reporting debate: Seemingly intractable problems and feasible solutions. European Accounting Review, 21(2), 193-215.

Vik, C., \& Walter, M. (2017). The reporting practices of key audit matters in the Big five audit firms in Norway (Master's Dissertation). BI Norwegian Business School, Oslo.

Yang, L., Brink, A, \& Wier, B. (2018). The impact of emotional intelligence on auditor judgement. International Journal of Auditing, 22(1), 83-97.

Yatim, P., Kent, P., \& Clarkson, P. (2006). Governance structures, ethnicity, and audit fees of Malaysian listed firms. Managerial Auditing Journal, 21(7), 757-782.

Ye, P., Carson, E., \& Simnett, R. (2011). Threats to auditor independence: The impact of relationship and economic bonds. Auditing: A Journal of Practice \& Theory, 30(1), 121-148.

Zanchun, X., Chun, C., \& Jianming, Y. (2010). Abnormal audit fees and audit opinion. Further evidence from China's capital market. China Journal of Accounting Research, 3(1), 51-70. 